\title{
Od PAUZANIASZA DO BAEDEKERA I SERWISU TRIPADVISOR: PROTOTURYZM TEKSTUALNY ORAZ ZAGROŻENIA DLA KANAŁÓW DYSTRYBUCJI TURYSTYCZNEJ
}

\author{
Vicky Katsonia ${ }^{\text {iD, Anna Fytab }}$ \\ a Uniwersytet Zachodniej Attyki, Katedra Zarządzania Turystyką; https://orcid.org/0000-0002-4808-9564; e-mail: katsoniv@uniwa.gr \\ b Athens College, Katedra Filologii Angielskiej; e-mail: annafyta@gmail.com
}

\begin{abstract}
ABSTRAKT
Głównym celem autorek artykułu jest interdyscyplinarne spojrzenie na turystykę i jej diachroniczne wątki tekstualne w prototurystycznych pismach Pauzaniasza - greckiego autora opowieści o podróżach. Korzystając z periegetycznych tekstów podróżniczych, zaczerpniętych z jego obszernego dzieła Wędrówki po Helladzie (Periegesis tes Hellados; II w. n.e.), będącego punktem wyjścia do rozważań, autorki zamierzają pokazać, że strategie tekstualne Pauzaniasza wciąż stanowią podstawę współczesnej serii przewodników turystycznych, zapoczątkowanej przez K. Baedekera w XIX w. Celem opracowania jest również wykazanie, że po Baedekerze tradycyjne teksty podróżnicze Pauzaniasza nadal mają wpływ na epistemologię współczesnej turystyki: interakcje między tekstami podróżniczymi, zawierającymi informacje turystyczne, a kanałami dystrybucji prowadzą do pojawienia się generycznych hybryd, a starożytni greccy autorzy podróży utorowali drogę do tworzenia cyfrowych opowiadań, sieci i globalnych platform turystycznych.
\end{abstract}

\section{SŁOWA KLUCZOWE}

opowieść cyfrowa, digital storytelling, Pauzaniasz, prototuryzm, opowieść podróżnicza, przewodniki turystyczne

\section{INFORMACJE O ARTYKULE}

Przyjęto:

22 października $2020 \mathrm{r}$.

Zaakceptowano:

13 kwietnia $2021 \mathrm{r}$.

Opublikowano:

11 czerwca $2021 \mathrm{r}$.

\section{WPROWADZENIE}

„Nienawidzę podróży i podróżników. Mimo to proponuję czytelnikom opowieść o moich wyprawach" - pisał L. Strauss, wybitny młody antropolog i uczony, przypuszczalnie "najsłynniejszy akademik” swoich czasów, autor melancholijnego dziennika podróży z 1936 r. pt. Smutek tropików (Tristes Tropiques) (McSweeney, 2015). Kilka tysiącleci przed nim Hezjod - Grek, który jako pierwszy opowiedział o mitach, bogach i śmiertelnikach w swoich dziełach Narodziny bogów (gr. Theogonia) oraz Prace i dnie (gr. Érga káj heméraj) - również przyznawał, że nie znosi podróżowania i unika go, jak może, dodając jednak, że jest to czasem zło konieczne. Homer nie ujawniał swoich odczuć; wykreował natomiast archetyp człowieka-podróżnika - Odyseusza. Chociaż same podróże bohatera nie były najważniejszym elementem Iliady, było to jednak dzieło, dające początek topografii kulturowej, co widać w spisie floty greckiej u wejścia do portu w Aulis podczas trwającego 10 lat oblężenia Troi.

Opowieści podróżnicze i zorganizowane podróże absolutnie nie są niczym nowym. Autorzy, tacy jak Tukidydes i Herodot, pisali dzieła historyczne, jednak są one wzbogacone osobistymi spostrzeżeniami, jak również informacjami uzupełniającymi i źródłami dotyczącymi miejsc geograficznych, ludzi, ich religii, zwyczajów i tradycji. Podobnie jest w przypadku wojskowej autobiografii Ksenofonta, pt. Anabasis (ok. 470 r. p.n.e.), przez wielu uważanej za najstarszy 
tekst periegetyczny (Hutton, 2005), chociaż Pretzler (2011) twierdzi, że pierwszą relacją podróżniczą była fikcyjna Arimaspeia - poemat napisany prawdopodobnie na początku VI w. p.n.e. przez Aristeasa z Prokonnesos. Autorzy ci często nie mogli się powstrzymać od zamieszczania szczegółów niezwiązanych z historią.

Przykładowo Herodot w Historiae (440 r. p.n.e.) informuje czytelników, że kobiety z plemienia Adurmachdae, żyjącego na granicy między Libią a Egiptem, „,noszą obręcze z brązu na szyi, zapuszczają długie włosy, a kiedy kobieta znajdzie wesz, rozgryza ją z nienawiścią i wyrzuca. To jedyne Libijki, które tak robią" (Redfield, 1985, s. 97-98). Herodot, zaszokowany i prawdopodobnie lekko zniesmaczony lub rozbawiony widokiem tej otwartej wojny z insektami, pisze jak turysta, myśląc na głos. W jego uwagach znajduje odbicie zjawisko „heterotematyczności" - terminu, którego Lowe (1991) używa w studium Critical terrains: French and British orientalisms do opisania wrodzonych cech heterogenicznych oraz braku wzajemnych odniesień między kulturami. Jednakże cytowany uprzednio fragment $\mathrm{z}$ dzieła Herodota zawiera generyczne cechy, na których opiera się dzisiejsze pisarstwo turystyczne: anegdotyczna narracja, opis, uszczypliwość, świadectwo dawane w pierwszej osobie, sensacjonalizm oraz ukryty komentarz odautorski na temat odmienności plemienia. Musiało upłynąć niemal siedem wieków, by pojęcia, takie jak: periegetyka (gr. periegesis) oraz piśmiennictwo periegetyczne, lub - innymi słowy - zbiór tekstów zawierających obserwacje poczynione na przestrzeni czasu (na co wskazuje grecki przedrostek peri-) podczas podróży po obszarze danego regionu geograficznego, nabrały obecnego znaczenia.

Obszerne dzieło Pauzaniasza, Greka urodzonego ok. 140 r. p.n.e. w Lidii, zatytułowane Periegesis lub Wędrówki po Helladzie, jest przykładem piśmiennictwa podróżniczego (obecnie niezależny gatunek), w którym czytelnicy mają być zaangażowani w relacjonowanie doświadczeń z podróży. Ta różnorodna, wielorodzajowa opowieść zawiera zapis uważnych obserwacji otoczenia fizycznego, jego analizę, odwołania do źródeł wtórnych oraz informacje archeologiczne, historyczne, polityczne, kulturowe i religijne. Podkreślając znaczenie tekstu Pauzaniasza i różnych punktów widzenia w nim zawartych, Hutton (2005, s. 3) pisze, że w tym szczególnym dzienniku podróży czytelnik odnajdzie również „wyjaśnienie mitów opowiadanych przez autora, potwierdzenie lub zaprzeczenie snutych przez niego opowieści historycznych oraz szczegółowe zestawienia jego opisów z najnowszymi odkryciami archeologicznymi".

Celem niniejszej pracy nie jest rozprawienie się z generyczną tożsamością Wędrówek po Helladzie autorstwa Pauzaniasza lub wyjaśnienie towarzyszących jej kontrowersji. Autorki podejmuja próbę zapoczątkowania i rozwinięcia debaty na temat interdyscyplinarnych związków między literaturą turystyczną a epistemologią współczesnej turystyki. Autorki zilustruja, jak wyraźna linia tekstu łączy to, co jest rozumiane jako autorstwo podróży, pisanie o podróżach, turyście i turystyce.

Ponadto autorki chciałyby wprowadzić do użytku termin „prototurystyka”, którego głównym pomysłodawcą i krzewicielem był Pauzaniasz. W swoim prototurystycznym tekście Wędrówki po Helladzie utorował on drogę dla przemysłu turystycznego, najpierw stwierdzając potrzebę ustalenia powszechnego, praktycznego kodu dla podróżników, a następnie przewidując, że zjawisko turystyki to znacznie więcej niż artystyczne i kulturowe doświadczenie wykształconego periegety.

\section{PRZESŁANKI TEORETYCZNE}

W starożytnych cywilizacjach, takich jak grecka, panowały głęboko zakorzenione przekonania dotyczące turystyki, rozrywki i rekreacji. Cytując El-Haramiego (2015, s. 168):

Grecy wierzyli, że przeznaczenie pewnego czasu na przyjemność, jaką dają człowiekowi muzyka, sztuka oraz uprawianie innych rodzajów aktywności w czasie wolnym, stanowi niezwykle istotny aspekt dobrego życia oraz fizyczny i duchowy klucz do szczęścia. Przekonanie to wywiera duży wpływ na dzisiejsze koncepcje.

W przypadku pisarstwa podróżniczego autor jest zaangażowany w nadawanie sensu doświadczeniom oraz negocjowanie „nowych tożsamości” (Roberson, 2007), a równocześnie próbuje on zrozumieć siebie (Schulz-Forberg, 2005). Bruner (2002, s. 64) pisze, że „mówienie o sobie jest jak wymyślanie historii o tym, kim i czym jesteśmy, co się wydarzyło i dlaczego to robimy".

Opowiadanie jest zasadniczo czynnością "postkonsumpcyjną" - ludzie tworzą historie, aby uporządkować swoje doświadczenia (Bosangit, McCabe, Hibbert, 2009; Escalas, 2004), porozumieć się z innymi (McCabe, Foster, 2006), opisać wspomnienia wydarzeń i działań, jak również ich znaczenie w kontekście tożsamości (Moscardo, 2010) oraz nadać kształt wspomnieniom i przeżyciom, które były ich udziałem (McGregor, Holmes, 1999). W konsekwencji opowiadanie historii pomaga zrozumieć doświadczenia turystyczne oraz jak twierdzą Woodside, Cruickshank i Dehuang (2007, s. 172), może ono być „,uważane za emiczną (tzn. dokonywaną z perspektywy lokalnego mieszkańca) interpretację tego, jak, dlaczego, kiedy i gdzie następują wydarzenia, oraz jakie są ich natychmiastowe i długoterminowe konsekwencje". W opowiadaniach zostały zawarte również struktury relacyjne i wymiary czasowe, które umożliwiają tworzenie znaczeń (Escalas, 2004). 
Opowieści podróżnicze stanowią podstawę konstrukcji doświadczeń turystycznych (McCabe, Foster, 2006) i odwrotnie - doświadczenia turystyczne są również zasobami narracyjnymi, które pozwalają przybierać i zmieniać tożsamość oraz w naturalny dla człowieka sposób rozumieć swoje życie (McAdams, 1996). Nasze doświadczenia z podróży, poprzez mówienie o nich w formie opowieści, stają się częścią tego, jak postrzegamy siebie i jak jesteśmy odbierani przez innych. Doświadczenia te są czasem „ikoniczne”, określające - budują naszą społeczną i prywatną tożsamość. Opowieść o doświadczeniach może też zawierać historie o światach społecznych (McCabe, Foster, 2006).

Opowieści podróżnicze nie tylko są odzwierciedleniem doświadczeń z podróży, ale również stanowią refleksję nad samym sobą. Kozinets, de Valck, Wojnicki i Wilner (2010) twierdzą, że chociaż autobiograficzne opowieści turystyczne podlegają przestrzennym i czasowym ograniczeniom doświadczenia turystycznego, zawierają one wybiórcze wspomnienia i przeżycia z naszego życia codziennego. Zatem narracja jest niezwykle ważna dla eksploracji i zrozumienia znaczeń w całym ludzkim życiu, włączając w nie doświadczenie turystyczne.

Pisarstwo podróżnicze i fikcja literacka często mają wspólny mianownik - niezbadaną płaszczyznę fizyczną i nieznane przestrzenie języka (Kelley, 2015). W przypadku obu tych elementów przekraczane są pewne granice i dlatego - generycznie rzecz ujmując - często wiążą się one ze sobą. Dziennik podróży może być sprzedawany w takich działach, jak: fikcja, dokument, historia, archeologia, podróże, autobiografia lub leksykony. Na przykład grecka wersja klasycznego osobistego pamiętnika Jacques'a Lacarrière'a pt. Promenades dans la Grece antique (greckie tłumaczenie oryginalnego tytułu brzmi: „Śladami Pauzaniasza”!) sprzedawana jest w sekcji Historia/Historiografia głównej księgarni w Atenach. Lacarrière świadomie zapisuje swoje własne doświadczenia emocjonalne i duchowe poprzez odtwarzanie tras, którymi podążał Pauzaniasz, i odwiedzanie miejsc, w których on był, ale wydawca zdecydował, że tekst sprzeda się lepiej w kategorii Historiografia niż Turystyka i podróże.

\section{OPOWIEŚCI PODRÓŻNICZE PRZED POJAWIENIEM SIĘ E-TURYSTYKI}

Pisarstwo podróżnicze jako systematyczna, ciągła opowieść często przypisywane jest Herodotowi, który w Historiae (V w. p.n.e.) w szczegółach opisał wyprawy wojenne, tworząc mieszaninę faktów i fikcji, prawdy i spekulacji, przeplatanych spostrzeżeniami antropologicznymi. Co ważne, dzieło to często postrzegane jest jako etnograficzny opis inności, przyjmujący formę porównań kultur i ludów w odwiedzanych krainach.
Herodot, tak jak Pauzaniasz, upiera się przy autopsji, akcie zobaczenia czegoś osobiście (Youngs, 2013). Dzięki tej metodzie - podobnie jak u Ksenofonta - podróżnik rekonstruuje wcześniejsze idee, które ostatecznie ułatwiłyby mu albo spowodowały redefinicję własnej tożsamości. Jednakże przypadek Pauzaniasza i jego dzienników podróży wykracza poza historyczną metodę stosowaną przez tych wybitnych Greków i wymaga dalszych badań nad wkładem tego geografa w powstanie turystyki, jaką dziś znamy.

Pauzaniasz w przedstawionym przez siebie, często niedocenianym opisie Grecji wyraźnie „odrzuca proste definicje”, odnosząc się do dziedzin „,klasycznej archeologii, starożytnej historii i klasyków [...] [i - przyp. autorek] ma potencjał, by stać się istotnym źródłem studiów nad odbiorem sztuki, historii, literatury komparatywnej (szczególnie podróżniczej)" (Pretzler, 2011, s. IX). Nieprzypadkowo w pierwszej połowie XX w. twórczość podróżnicza Pauzaniasza nie była już postrzegana jako uzupełniająca forma pisarstwa $\mathrm{w}$ literaturze modernistycznej, tworzonej przez takich autorów, jak: V. Woolf, E.M. Forster, T.S. Eliot czy H.D. (pseudonim pisarki i poetki amerykańskiego modernizmu - $\mathrm{H}$. Doolittle). Ostatnia z wymienionych osób podróżowała do Grecji dwukrotnie na początku lat 20. XX w., a w swoich Notes on Euripides, Pausanias and Greek lyric poets (H.D., 1919) zamieściła pięć felietonów w uznaniu dla Pauzaniasza, napisanych przez niego Wẹdrówek po Helladzie i wartości literackiej jego utworów. Zdaniem H.D. Pauzaniasz, „krajowy specjalista od podróżników”, zasługuje na podziw za ",olbrzymią bezosobowość", najlepiej widoczną w jego pełnej rezerwy postawie, gdy opowiadał o jakimś tajemniczym lub na wpół zapomnianym antycznym bóstwie (H.D., 1919, s. 2-3). Założenia zaprezentowane przez szkockiego antropologa Frazera (1890) w pracy zatytułowanej Złota gałaź (The golden bough: A study in comparative religion), zgodnie z którymi dzikość jest podstawą natury brytyjskiego społeczeństwa na równi z pogańskimi, prymitywnymi mitami, znajdują wyraźne odbicie w tekstach na temat podróżowania napisanych przez wspomnianych modernistów, jak również w ich własnych opowieściach podróżniczych. Wydaje się, że popisy erudycji, różne punkty widzenia, liczne źródła i bezosobowy autorytet leżą u podstaw pisarstwa podróżniczego i modernizmu, z jego eksperymentami oraz poszukiwaniem formalnej niestabilności i generycznej odnowy. Pauzaniasz zdaje się demonstrować wspomniane cechy w swoich nowoczesnych dziennikach podróży, a te $\mathrm{z}$ kolei stają się przydatne $\mathrm{w}$ tworzeniu współczesnych tekstów podróżniczych.

Trzy terminy, czy też kluczowe pojęcia przekazane nam przez Pauzaniasza i jego poprzedników stanowią sedno dyskursu na temat podróży w prototurystycznych opowieściach tego autora - w opisywaniu tego, co jest „warte odwiedzenia”, za niezbędne uznaje się pojęcie wybiórczości oraz procesu dialogicznego, 
w którym autor i czytelnik wspólnie korzystają z tego, co Pretzler identyfikuje jako: autopsia, logoi i theoremata. Pauzaniasz stosuje wszystkie trzy narzędzia metodologiczne w pierwszej części swojego dziennika podróży, zarysowując podstawy pisarstwa podróżniczego i przewidując potrzeby przyszłego turysty. Styl jest "prosty i bezpretensjonalny" (Pausaniasz, 1992, 3.16.10), jak pisze tłumacz we wstępie do wydania w serii Loeb (Loeb Edition). Sam Pauzaniasz jednoznacznie określa cel swojego dziennika podróży i toruje drogę temu, co obecnie określane jest jako warte odwiedzenia: „Takie, w mojej opinii, są najsłynniejsze legendy (logoi) i miejsca (theoremata) pośród Ateńczyków i od początku moje opowieści zawierały materiały wybrane spośród wielu wartych zapisania (autopsia)" (Pauzaniasz, 1992, 1.39.3).

Jeśli autor usiłuje nadać sens swoim podróżniczym doświadczeniom, to siłą rzeczy wnętrze i to, co na zewnątrz, stanowią konieczne i nierozerwalne części dyskursu podróżniczego. Według Pretzler (2011) logoi oznacza proces dokumentacji.

Przekazy mitologiczne i historyczne, jak również opowiadania lub porównania dotyczące historii stanowisk archeologicznych i innych są częścią interpretacji tego, co Pauzaniasz (1992, 3.16.10) określa jako „wszystko, co greckie”. Jednakże słowo theoremata (od greckiego czasownika theoro) z jednej strony sugeruje fizyczny akt zobaczenia czegoś, a następnie identyfikowanie fizycznych miejsc i podanie wizualnych szczegółów w różnych celach. Z drugiej strony theoro oznacza również konwersję wizualnego aspektu doświadczenia podróżniczego w spisaną , teorię". Innymi słowy, dokumentacja podróży pociąga za sobą konkretyzację prawdziwego lub wymyślonego doświadczenia $\mathrm{w}$ formie tekstu.

W XIX w. K. Baedeker, niemiecki literat i grekofil opisujący podróże, stał się jednym z pierwszych współczesnych pisarzy tego typu po Pauzaniaszu. Baedeker zamieścił szczegółowe deskrypcje swoich doświadczeń podróżniczych w Przewodniku dla podróżujacych po Grecji - pracy zawierającej charakterystykę ówczesnej Grecji oraz będącej odpowiedzią na rosnące zainteresowanie podróżami i zapotrzebowanie na informacje w stopniowo kształtującej się turystyce. W dziele tym Baedeker podejmował dyskusję ze swym wybitnym greckim poprzednikiem. W przewodnikach Baedekera zaprezentowane są jego własne podróże do innych krajów. Publikacje te stanowią zapowiedź Blue guides, ogłoszonych drukiem w 1918 r. przez braci Muirhead ze Szkocji, którzy nieprzypadkowo przez ponad dwie dekady pełnili funkcję anglojęzycznych wydawców niemieckiej serii Baedekera.

Egzegetyczna kombinacja logoi i theoremata Pauzaniasza narzuca Baedekerowi pojęcie wybiórczości stanowiącej ostateczny cel podróżnika periegety. We wstępie do drugiego wydania Przewodnika dla podróżujacych po Grecji z 1894 r., Baedeker napisał:
[Moim celem] jest dostarczenie podróżnikowi najpotrzebniejszych informacji dotyczacych historii i kultury narodu, który zamierza on odwiedzić, uniezależnić go w najwyższym stopniu od usług pilotów, przewodników i przedstawicieli, ochronić przed wykorzystaniem i w każdy możliwy sposób pomóc mu czerpać przyjemność i wiedzę z podróży po jednym z najbardziej fascynujących krajów na świecie (Baedeker, 1894, s. V).

Baedeker dość wiernie interpretuje Pauzaniasza. Najpierw zamyka pojęcie wybiórczości w trzech słowach: "najbardziej potrzebne informacje”, a następnie, używając przymiotnika "niezależny", daje podróżnikowi poczucie sprawczości w nieznanym, potencjalnie wrogim środowisku. Triangulacja między pisarzem-autorytetem, tekstem-informacją a czytelnikiem -poszukiwaczem staje się zarówno intelektualnym, jak $i$ intuicyjnym/instynktownym związkiem, obiecującym pozorne, jeśli nie paradoksalne poczucie swobody w ramach kilku rekomendowanych opcji. Naturalnie zarówno Baedeker, jak i Pauzaniasz piszą przede wszystkim dla odbiorców, którzy są podróżnikami związanymi z czasami antycznymi, poszukującymi przyjemności duchowej poprzez informacje na temat kultury. Niemniej jednak, czyż informacja nie gwarantuje również osiągnięcia celu podróży?

W przewodniku Baedekera znalazły się aż 102 odniesienia do Pauzaniasza i jego logoi. Opisowe i informacyjne części przewodnika niemal wiernie odtwarzają model periegesis, poprzez długie opowieści o historii sztuki greckiej. Jednocześnie Baedeker zamieszcza aluzje tekstowe do nowatorskiej książki Historia sztuki starożytnej niemieckiego historyka J. Winckelmanna. Baedeker krótko recenzuje ja twierdząc, że „nie jest to już ostateczny autorytet" (Baedeker, 1894, s. LXIV), a następnie komentuje tłumaczenie Winckelmanna wykonane przez H. Lodge'a. W stylu wybitnego estety, W. Patera, niemiecki autor przewodników snuje rozważania o istocie greckiej sztuki: „Prawda i piękno formy zostały uzyskane poprzez praktykę w męskich, choć w pewnym sensie sztywnych i ostro zarysowanych granicach" (Baedeker, 1894, s. LXV). Ponadto przelotnie odnosi się do Platona i jego teorii form: „Nie istnieje forma, która może oddać absolut" (Baedeker, 1894, s. LXVI). Najbardziej nowatorskim wkładem Baedekera w dialektykę logoi Pauzaniasza jest być może jego komentarz dotyczący „fikcjonalizacji” szczegółów podróży. Pauzaniasz i Homer powinni wyjaśnić kwestię Aulis i zebrania greckiej floty:

Tysiąc statków wspomnianych w Iliadzie w spisie okrętów nie mogło oczywiście stać na wodzie w zatoce w tym samym czasie. Musimy zatem myśleć o nich jako o statkach wyciągniętych na brzeg, zgodnie z miejscową tradycją jednocześnie pozwalając na późniejszą przesadę w opisie, kiedy narodziło się pragnienie zdobycia jakiegokolwiek miasta wspomnianego w homeryckich wierszach, bez względu na jego rangę (Baedeker, 1894, s. 184). 
Włączenie przez Baedekera theoremata Pauzaniasza do własnego Przewodnika świadczy zarówno o erudycji niemieckiego pisarza, jak i o konstruktywnym przejęciu tropologii podróżniczej wybitnego Greka. W dziennikach podróży / przewodnikach Baedekera po raz pierwszy zostają wprowadzone koncepcje/pojęcia, które Cohen określa jako pięć trybów turystyki: rekreacyjny, zmieniający rutynowe czynności człowieka, doświadczalny, eksperymentalny i egzystencjalny (Cohen, 1979). Ostatnie trzy tryby stanowią dość precyzyjne odzwierciedlenie aktualnych poszukiwań podróżniczych i są starsze niż współczesne, alternatywne formy turystyki, oparte na koncepcji autentyczności poprzez wyodrębnienie fragmentów prawdziwego żywota innych, jak dzieje się to $\mathrm{w}$ przypadku, gdy podróżnik podejmuje wędrówkę zmieniającą jego życie.

W podobny sposób Baedeker proponuje szczegółową trasę objazdu ważnych miejsc, prawdopodobnie po raz pierwszy z pomocą załączonych rozkładanych map. W przewodniku podano również informacje na temat eksponatów/wystaw muzealnych, wprowadzono topografię wizualna, listę nazw w języku angielskim oraz niekiedy zamieszczano kluczowe terminy niemieckie i greckie. Kryteria wyznaczania tras zastosowane w Przewodniku to odległość w milach i czas potrzebny, by przemieścić się z jednego miejsca do drugiego: „Dotarcie do ruin [w Delfach - przyp. A.F.] wymaga pięciu godzin [z Itei - przyp. A.F.]. Podążając za opisem Pauzaniasza, rozpoczynamy naszą pielgrzymkę" (Baedeker, 1894, s. 154). Pauzaniasz odgrywa rolę przewodnika-cienia, rekomendującego miejsca do zwiedzenia oraz oferującego starą narrację, poddawaną rewizji i ponownej interpretacji. Zwiedzaniu poszczególnych obszarów lub miejsc towarzyszą zwięzłe, lecz wyraziste komentarze, dotyczące spraw praktycznych, takich jak zakwaterowanie czy wyżywienie. W Tebach np. „,warunki zakwaterowania są bardzo wątpliwej jakości, a jedyne względnie porządne miejsce to Xenodocheion Boiotia, którym zarządza Drakos. Jedyna akceptowalna gospoda to Dimitra, prowadzona przez Belosa" (Baedeker, 1894, s. 176). W przewodniku autor wprowadza podstawowy słownik / listę greckich słów i wyrażeń, pomagających podróżnikowi poradzić sobie podczas codziennych interakcji. Społeczno-kulturowy komentarz Baedekera, używającego określeń wartościujących, takich jak ,akceptowalny" i ,wątpliwy", aby ocenić doświadczenie podróży, $w$ tym również szczegóły zawartych transakcji finansowych, poprzedza serię drukowanych przewodników zwiastujących nadejście XX w. i przekonanie konsumenta/podróżnika do koncepcji turystyki masowej.

Schyłek XIX w. to czas narodzin lukratywnego rynku opartego na kształtującym się przemyśle turystycznym. Rynek ten musi wzbogacić doświadczenia potencjalnego podróżnika o opinie i polecenia, często napisane przez wybitnych autorów, którzy potrafią uwierzytelnić podróże jako formę wspólnego i indywidualnego odkrywania. Na przykład książka In darkest Africa H.M. Stanleya (1890) sprzedała się w liczbie 150000 egzemplarzy w ciągu pierwszych dwóch tygodni od publikacji. Została przetłumaczona na pięć języków. Historiograficzna narracja podróżnicza Stanleya to opowieść o ekspedycji Leopolda II, króla Belgii, który miał nadzieję zdobyć Sudan. Teraz turyści mogą stać się gawędziarzami, autorami introspektywnych opisów ich własnych doświadczeń i uczuć (Pace, 2008). Jak twierdzą McCabe i Foster (2006), turyści mogą wejść w rolę narratora. Przekazują oni swoje wspomnienia z podróży, $\mathrm{z}$ wizyt $\mathrm{w}$ rozlicznych miejscach oraz ze spotkań z różnymi ludźmi poprzez historie oraz opisy tego, co przeżyli, ułożone tematycznie i chronologicznie. Pauzaniasz i Baedeker zaoferowali współczesnym turystom wspólne doświadczenie. W ten sposób zostały stworzone podwaliny przemysłu turystycznego.

\section{PISARSTWO PODRÓŻNICZE A FIKCJA LITERACKA W DOBIE E-TURYSTYKI}

Informacja i dystrybucja turystyczna może być wdrażana za pośrednictwem wielu różnych kanałów, tj. ścieżek, które interesariusze branży turystycznej wykorzystują do komunikacji, przekazu informacji, jak również sprzedaży produktów i usług. Wszyscy dostawcy produktów turystycznych są zależni od tych kanałów, choć oczywiście w różnym stopniu. Przed 1970 r., w warunkach tradycyjnej dystrybucji, interesariusze branży turystycznej $\mathrm{w}$ dużej mierze polegali na pośrednikach, takich jak: biura podróży, globalne systemy dystrybucji (GDS), przewodniki, czasopisma i ulotki, przekaz ustny itd.

Niemniej jednak mnóstwo badań potwierdza, że w dzisiejszych czasach to Internet jest najważniejszym kanałem dystrybucji w turystyce. Internet zapoczątkował epokę elektroniczną (e-turystykę), w której turystyka „wciąż redefiniuje się i wymaga ciągłej reorientacji w sferze marketingu i zarządzania, na bieżąco" (Katsoni, 2016, s. 21). Internet wraz z nowymi, interaktywnymi środkami komunikacji poprzez narzędzia rezerwacji online, takie jak: internetowe biura podróży (OTAs), strony z ofertami last minute i sprzedażą błyskawiczną (flash-sale), jak również wirtualne społeczności turystyczne, media społecznościowe czy urządzenia mobilne, fundamentalnie zmieniły sposób podróżowania i marketingu, jako że wszyscy interesariusze branży mają obecnie możliwość wspólnego wzmacniania swoich doświadczeń (Gretzel, Fesenmaier, Formica, O'Leary, 2006; Neuhofer, Buhalis, Ladkin, 2014).

Wykorzystywanie technologii informacyjnych i komunikacyjnych (ICTs) w turystyce może zwiększyć zaangażowanie i współtworzenie doświadczeń przez konsumenta na kilka sposobów, np. poprzez dzielenie się informacjami dotyczącymi interesujących miejsc do 
zwiedzania, zakwaterowania, sprzedaży, szczegółów na temat danej miejscowości itp. (Gretzel, Jamal, 2009; Neuhofer, Buhalis, Ladkin, 2014; Sabou, Nistoreanu, Vlad, 2014; Tussyadiah, Fesenmaier, 2016).

Od czasów Pauzaniasza i Baedekea wykorzystywanie narracji nadal zapewnia „,konkretne” doświadczalne aspekty podróży (Gretzel, Fesenmaier, Formica, O’Leary, 2006; Mattila, Enz, 2002). Opowieść cyfrowa (digital storytelling) łączy w sobie sztukę opowiadania historii z różnorodnością cyfrowych multimediów, takich jak: grafika, tekst, nagrana narracja audio, muzyka i wideo (Robin, 2008). Opowiadanie cyfrowe jako strategia narracyjna polega na ,przekazywaniu osobistych historii z wykorzystaniem form cyfrowych, oraz na przechowywaniu tych historii i wymienianiu się nimi na stronach i platformach, które nie istniałyby bez sieci WWW i które - dzięki potencjałowi mediów cyfrowych - dają wiele możliwości przekazu" (Couldry, 2008, s. 374). Opowieść - jedna z najpotężniejszych metod stosowanych, by tchnąć życie w branżę turystyczną - często zaliczana jest do głównych komponentów marketingu treści (content marketing). Przez nadanie produktom i usługom tożsamości oraz poprzez tworzenie opowieści i dzielenie się nimi w miejscach turystycznych można zabrać klientów docelowych w wymarzoną podróż, jak również poprawić reputację atrakcji turystycznych (Bassano i in., 2019; Wu, 2006).

Okazuje się, że gdy turyści pozostają pod silnym wpływem opowieści cyfrowej, angażują się w ten proces i chętnie dzielą się swoimi doświadczeniami z podróży za pośrednictwem mediów cyfrowych (Bassano $\mathrm{i}$ in., 2019; Hassan, 2016; Klimmt, Roth, Vermeulen, Vorderer, Roth, 2012; Wu, 2006). Aby nawiązać więź z każdą miejscowością lub przedsiębiorstwem turystycznym, konsument musi postrzegać te cyfrowe historie jako autentyczne, twórcze i inspirujące i w rezultacie być otwarty na stworzenie silnego związku emocjonalnego z daną miejscowością. W dobie e-turystyki narracja oraz interaktywny charakter historii opowiadanych w pierwszej osobie to cechy charakterystyczne stron internetowych biur podróży (np. Booking.com), recenzji zamieszczanych w sieci na specjalistycznych platformach (np. TripAdvisor.com), organizacji zajmujących się marketingiem destynacji (DMOs) i różnych mediów społecznościowych.

Blogi podróżnicze - popularna hybrydowa forma pisania w Internecie - stanowią jeden z najlepszych przykładów współczesnego rodzaju narracji w pisarstwie podróżniczym i są cyfrową wersją przekazu ustnego i opowiadania historii (Jeuring, Peters, 2013; Pudliner, 2007). Według Carù i Covy (2008, s. 168) blogerzy są „zastanawiającymi się nad sobą jednostkami, które własnymi słowami, przydatnymi do zrozumienia subiektywnego wymiaru doświadczenia, opowiadają historie i wyjaśniają swoje działania". Blog to nie tylko reportaż o miejscach, ludziach i kulturze. Stanowi on również źródło informacji o autorze i jego świecie, jest sposobem blogera na wyrażenie siebie i dzielenie się pozytywnymi i negatywnymi doświadczeniami podróżniczymi (Schmallegger, Carson, 2008) oraz jego spostrzeżeniami na temat innych ludzi (Bohls, Duncan, 2005). Na blogach podróżniczych, które mogą być uznane za wyraz konsumpcji podróży (Bosangit, Hibbert, McCabe, 2015), turyści dzielą się przeżyciami, nastrojami i odczuciami (Volo, 2010). Blogi w dużej mierze opierają się na ustnej formie przekazu z perspektywy blogera - naocznego świadka. Na wpół dziennikarskie aspiracje autora jako osoby posiadającej fachową wiedzę obiektywnego profesjonalisty przyjmują formę wyznania w intymnym, osobistym tonie. Tussyadiah i Fesenmaier (2016) zwracają uwagę na pojawienie się pisarzy cyfrowych na blogach, w mediach społecznościowych, w opiniach w Internecie itd.

Bloger redefiniuje pojęcie tożsamości turystycznej i umożliwia swoim czytelnikom dostęp do różnych swoich wcieleń, wykreowanych za pomocą form aktywności, postaw i wartości. Tworzą one kluczowy element marketingu, zwany charakteryzacją. Kategoryzacja przestrzeni to jego inny ważny komponent stanowiący prezentację oceny i wyników przebiegu opowieści, który umożliwia czytelnikom poznanie konstrukcji hipotetycznych scenariuszy podróży oraz podejmowanie prób odgrywania ich. W analizie tych scenariuszy uwzględniono jeszcze dwa dodatkowe kluczowe elementy marketingowe, tj. produkt całościowy (overall product) oraz ocenę doświadczenia.

Badania nad opowieścią cyfrową (digital storytelling) przeważnie dotyczą głównych pojęć, takich jak: atrakcyjność estetyczna, treść zorientowana na konsumenta, narracja, konfiguracja oraz odniesienia do samego siebie (Bonacini, Tanasi, Trapani, 2018; Robin, 2008). Według Lavie i Tractinsky'ego (2004, s. 272), ,postrzegana estetyka jest percepcją ludzi, natury lub artefaktów o artystycznie pięknym lub przyjemnym wyglądzie". W strukturę narracji wpisane są elementy czasowości i chronologii (początek, środek i zakończenie), jak również przypadkowości w relacjach (Delgadillo, Escalas, 2004). Ta ostatnia wpływa na emocjonalną reakcję czytelnika wynikającą z kolejności, w jakiej napotyka on te relacje (Escalas, Stern, 2003). Odniesienia do samego siebie dotyczą „doświadczeń lub wspomnień «widzów», które mogą trafiać w ich czułe struny" (Hsiao, Lu, Lan, 2013, s. 174).

Zatem doświadczenie turystyczne jest (re)prezentowane, (re)produkowane i (od)tworzone poprzez opowieść we wszystkich tradycyjnych i cyfrowych kanałach dystrybucji (Woodside, 2010). Turyści wykorzystują je z kolei do interpretowania otaczającego świata nie tylko w celu tworzenia znaczenia i pobudzania swojej wyobraźni (Escalas, 2004), ale również po to, by oceniać innych ludzi, przedmioty i wydarzenia (Schank, Abelson, 1995), zrozumieć (Noy, 2004) 
i doświadczać samego siebie w jakimś miejscu (Cutler, Carmichael, 2010), a nawet odegrać rolę w kształtowaniu wspomnień o doświadczeniu na przestrzeni czasu (McGregor, Holmes, 1999).

\section{5. ŁĄCZĄC PRZESZŁOŚĆ Z TERAŹNIEJSZOŚCIĄ: PODRÓŻE, TURYSTYKA I NOWE ODWOŁANIA TEKSTOWE}

Gdyby Pauzaniasz lub Baedeker pisali w naszych czasach, byliby popularnymi blogerami lub głównymi administratorami portalu Tripadvisor. Współcześnie autorzy tworzą teksty przypominające dawne utwory z uwagi na uwzględnianie autopsies, theoremata i logoi w celu zdobycia wiarygodności i autorytetu. E-turystyka wywiera coraz większy wpływ na turystów poprzez siłę swojej narracji. Opowieści o popsutych kranach i brudnej pościeli w pięciogwiazdkowym hotelu, przeczytane na Tripadvisor czy Booking.com, wpływają na emocje i wyobraźnię czytelników, podobnie jak wtedy, gdy Baedeker w XIX w., po swojej krótkiej wycieczce do Teb w Grecji, bezlitośnie krytykował gospodę u Drakosa za jej niedopuszczalnie brudne otoczenie. Opowieść Pauzaniasza o "poplamionym krwią ołtarzu bogini Artemidy” oraz "biczowaniu młodych chłopców", by ołtarz był nieustannie zachlapany ludzką krwią (Pausaniasz, 1992, 3.16.10), musiała w czasach autora wywierać podobny wpływ na wykształconych odbiorców, czytających te sensacyjne opisy.

Podróżnicy mają potrzebę komunikowania swoich przeżyć (Mattila, Enz, 2002) i wykorzystywania historii, które są przekonujące dzięki przeniesieniu narracyjne$\mathrm{mu}$, polegającemu na immersji (Green, Brock, Kaufman, 2004). Co więcej, doświadczenie jest przekazywane i wyrażane poprzez opowieści, które składają się z faktów lub sekwencji wydarzeń połączonych ze sobą we wzór lub strukturę symbolizującą to doświadczenie (Mattila, Enz, 2002). Za sprawą elementów opowieści stanowiących odwołania do samego siebie zostają wywołane wspomnienia przeszłych osobistych doświadczeń. $W$ ten sposób podróżnicy mogą umieścić się w opowieści, jakby byli jej prawdziwymi bohaterami (Escalas, Stern, 2003; Freedberg, Gallese, 2007). Prototurystyczne, periegetyczne opowiadania Pauzaniasza odznaczają się struktura, zasadzającą się przede wszystkim na podstawowych współczesnych elementach marketingu, o których wcześniej wspomniano (Tussyadiah, Fesenmaier, 2016). Ponadto Pauzaniasz zyskuje dostęp do przybranych wcieleń, stworzonych poprzez działania, postawy i wartości. Prezentuje on krytyczną ocenę oraz efekty sekwencji narracyjnych, a potem wartościuje swoje doświadczenie.

Wydaje się, że znany od dawna proces „mówienia o doświadczeniach turystycznych, które są narzędziem konstruowania i reprezentowania tożsamości" (Desforges, 2000, s. 928), lub „opowiadania o przemianach zachodzących w człowieku i opisywania rytuału przejścia" (White, White, 2004, s. 211) pozostaje niezmienny aż do dziś. Turystyka według Pauzaniasza wciąż leży u podstaw współczesnych przewodników turystycznych, wydawanych w takich seriach, jak Fodor's Travel Guides czy Lonely Planet. Pauzaniasz bazował na swoich własnych doświadczeniach, by opisać związane z nimi miejsce tak dokładnie, jak to możliwe (Harloe, 2010; MacCormack, 2010). Obecna dystrybucja informacji podróżniczych i turystycznych na popularnych platformach tekstowych, takich jak wydania oraz sieci medialne serwisów Lonely Planet lub Tripadvisor, łączy w sobie ukryty przekaz i przekonujący charakter opowieści, jak również ma pozytywny wpływ na daną destynację turystyczna, jeśli uznamy ją za markę samą w sobie.

\section{WNIOSKI}

Pod wieloma względami przeplatana, trójwarstwowa struktura topograficznych opisów Pauzaniasza (omówione wcześniej autopsia, theoremata i logoi) stanowi prototurystyczny wzór dla współczesnego podejścia do opowiadania historii. Jednakże Pauzaniasz, daleki od bycia empirysta, kreuje w swoich tekstach obrazy miejscowości poprzez kulturowo zdeterminowaną gramatykę, tworząc raczej poczucie, rozumienie miejsca niż jego definicję. W niniejszym artykule omówiono, w jakiej formie przetrwały teksty Pauzaniasza, jak zostały „przetłumaczone” i w jaki sposób nawiązywali do nich Baedaker i jemu współcześni oraz twórcy obecnie rozpowszechnianych informacji turystycznych.

Opierając się na podstawowych zasadach tworzenia tekstów zawierających informację turystyczna, autorki przefiltrowały je przez różne kanały dystrybucji turystycznej. Z kolei w świecie turystyki cyfrowej na popularnych stronach internetowych, blogach i w mediach społecznościowych proponowane jest nowe podejście do turystyki, która wcześniej była domeną przewodników drukowanych. Ostra konkurencja na rynku turystycznym zachęca interesariuszy branży turystycznej oraz internetowych dostawców informacji, takich jak: organizacje turystyczne, hotele i ośrodki wypoczynkowe, biura podróży, blogerzy i czasopisma, do znajdowania nowych sposobów oraz opracowywania koncepcji i strategii promowania ich destynacji turystycznych, jak również do aktywnej rywalizacji o uwagę osób, poszukujących i ostatecznie dokonujących rezerwacji (Govers, Go, Kumar, 2007).

Obecnie, bez względu na rodzaj kanału dystrybucji turystycznej, nacisk kładziony jest na formę opowiadania, co w istocie oznacza stosowanie praktyk Pauzaniasza, tyle że w nowym wydaniu. 
Odnosząc się do wybiórczości pamięci, M. Faucault pisał, iż jej wybory to bardzo ważny element percepcji samego siebie w każdej grupie, co stało się przyczynkiem do dyskusji. Według Foucalta kontrola pamięci społecznej wiąże się bezpośrednio z kwestiami hierarchii i autorytetu (Faustino, Ferraro, 2020). Wydaje się, że osoby zatrudnione $\mathrm{w}$ nowoczesnym przemyśle turystycznym mają wiedzę na ten temat, o czym świadczy widoczna w tym środowisku obsesja na punkcie rankingów, ocen i recenzji publikowanych na liście najlepszych i najgorszych restauracji na świecie. Pomimo to wielogłosowe pisarstwo Pauzaniasza, jego holistyczne podejście do tworzenia kontekstu, jak również charakterystyczna dla jego utworów konstrukcja czasu i pamięci oraz wybiórczość zaprzeczają temu założeniu. Pauzaniasz z powodzeniem tworzy nieśmiertelną opowieść (Stewart, 2013), w której pomimo szczegółowych opisów krajobrazu, mitycznych bohaterów i ważnych polityków czy artystów, przez które czasem trudno przebrnąć, świetnie odbudowuje i jednocześnie zachowuje archiwalne wcielenia mitologiczno-historycznej tradycji.

Co ciekawe, z biegiem czasu interakcja między tekstami podróżniczymi zawierającymi informację turystyczną a kanałami dystrybucji doprowadziła do powstania hybryd generycznych, tj. tekstów podróżniczych, dostarczających informacji na podstawie kombinacji opowieści podróżniczych i informacji o usługach. Teksty te są unikatowe pod względem konstrukcji i źródła inspiracji, ale wciąż opierają się na tych samych zasadach, mających na celu zaangażowanie turysty w podróż. Dostarczają one informacji dla przyszłych turystów poprzez zestawienie produktów turystycznych i ustanowienie mechanizmów, które umożliwiają konsumentom dokonanie, potwierdzenie i opłacenie rezerwacji. Czy w przypadku nowych, e-turystycznych mediów powinno się rozważyć powrót do praktyk Pauzaniasza?

\section{BIBLIOGRAFIA}

Baedeker, K. (1894). The traveler's handbook to Greece. Wyd. 2. Leipsic: Karl Baedeker, Publisher.

Bassano, C., Barile, S., Piciocchi, P., Spohrer, J.C., Iandolo, F., Fisk, R. (2019). Storytelling about places: Tourism marketing in the digital age. W: J.S. Santos, Ó. Lima (red.), Digital marketing strategies for tourism, hospitality, and airline industries (s. 1020). USA: IGI Global. https://doi.org/10.1016/j.cities.2018.12.025

Bohls, E., Duncan, I. (2005). Travel writing, 1700-1830: An anthology. Oksford: Oxford Press.

Bonacini, E., Tanasi, D., Trapani, P. (2018). Digital heritage dissemination and the participatory storytelling project \#iziTRAVEL Sicilia: The case of the archaeological Museum of Syracuse (Italy). Acta Imeko, 7 (3), 31-39. https://doi.org/10.21014/acta_ imeko.v7i3.584

Bosangit, C., Hibbert, S., McCabe, S. (2015). If I was going to die I should at least be having fun: Travel blogs, meaning and tourist experience. Annals of Tourism Research, 55, 1-14. https:// doi.org/10.1016/j.annals.2015.08.001
Bosangit, C., McCabe, S., Hibbert, S. (2009). What are told in travel blogs? Exploring travel blogs for consumer narrative analysis. Amsterdam: Springer-Verlag. https://doi.org/10.1007/978-3-211-93971-0_6

Bruner, J. (2002). Making stories: Law, literature, life. Cambridge: Harvard U Press.

Carù, A., Cova, B. (2008). Small versus big stories in framing consumption experiences. Qualitative Market Research: An International Journal, 11 (2), 166-176. https://doi.org/10.1108/13522750810864422

Cohen, E. (1979). The phenomenology of tourist experiences. Sociology, 13, 179-201. https://doi.org/10.1177/003803857901300203

Couldry, N. (2008). Mediatization or mediation? Alternative understandings of the emergent space of digital storytelling. New Media \& Society, 10 (3), 373-391. https://doi. org/10.1177/1461444808089414

Cutler, S., Carmichael, B. (2010). The dimensions of tourist experience. W: M. Morgan, P. Lugosi, J.R. Brent Richie (red.), The tourism and leisure experience. Consumer and management perspective (s. 3-26). Bristol: Channel View Publications. https:// doi.org/10.21832/9781845411503-004

Delgadillo, Y., Escalas, J.E. (2004). Narrative word-of-mouth communication: Exploring memory and attitude effects of consumer storytelling. Advances in Consumer Research, 31 (1), 186-193.

Desforges, L. (2000). Travelling the world: Identity and travel biography. Annals of Tourism Research, 27 (4), 926-945. https:// doi.org/10.1016/S0160-7383(99)00125-5

Egger, R., Buhalis, D. (2008). Introduction. W: R. Egger, D. Buhalis (red.), eTourism case studies: Management $\mathcal{E}$ marketing issues in eTourism (s. 1-3). Węgry: Butterworth-Heinemann.

El-Harami, J. (2015). Entertainment and recreation in the classical world - tourism products. Journal of Management and Sustainability, 5 (1), 168-178. https://doi.org/10.5539/jms.v5n1p168

Escalas, J. (2004). Narrative processing: Building consumer connections to brands. Journal of Consumer Psychology, 14 (1), 168-180. https://doi.org/10.1207/s15327663jcp1401\&2_19

Escalas, J.E., Stern, B.B. (2003). Sympathy and empathy: Emotional responses to advertising dramas. Journal of Consumer Research, 29 (4), 566-578. https://doi.org/10.1086/346251

Faustino, M., Ferraro, G. (2020). The late foucault: Ethical and political questions. Londyn: Bloomsbury.

Frazer, J.G. (1890). The golden bough: A study in comparative religion. Londyn: Macmillan.

Freedberg, D., Gallese, V. (2007). Motion, emotion and empathy in esthetic experience. Trends in Cognitive Sciences, 11 (5), 197-203. https://doi.org/10.1016/j.tics.2007.02.003

Govers, R., Go, F.M., Kumar, K. (2007). Virtual destination image a new measurement approach. Annals of Tourism Research, 34 (4), 977-997. https://doi.org/10.1016/j.annals.2007.06.001

Green, M.C., Brock, T.C., Kaufman, G.F. (2004). Understanding media enjoyment: The role of transportation into narrative worlds. Communication Theory, 14 (4), 311-327. https://doi. org/10.1111/j.1468-2885.2004.tb00317.x

Gretzel, U., Fesenmaier, D.R., Formica, S., O’Leary, J.T. (2006). Searching for the future: Challenges faced by destination marketing organizations. Journal of Travel Research, 45 (2), 116-126. https://doi.org/10.1177/0047287506291598

Gretzel, U., Fesenmaier, D.R., O'Leary, J.T. (2006). The transformation of consumer behavior. W: D. Buhalis, C. Costa (red.), Tourism business frontiers: Consumers, products and industry (s. 9-18). Oksford: Elsevier. https://doi.org/10.1016/ B978-0-7506-6377-9.50009-2

Gretzel, U., Jamal, T. (2009). Conceptualizing the creative tourist class: Technology, mobility, and tourism experiences. Tourism Analysis, 14 (4), 471-481. https://doi.org/10.3727/10835420 9X12596287114219

H.D. (Hilda Doolittle) (1919). Notes on Euripides, Pausanius and Greek lyric poets. New Haven: Beinecke Rare Book and Manuscript Lib. 
Harloe, K. (2010). Pausanias as historian in Winckelmann's history. Classical Receptions Journal, 2 (2), 174-196. https://doi. org/10.1093/crj/clq009

Hassan, A. (2016). Electronic word-of-mouth: An industry tailored application for tourism promotion. W: S. Rathore, A. Panwar (red.), Capturing, analyzing, and managing word-of-mouth in the digital marketplace (s. 61-75). UK: IGI Global. https:// doi.org/10.4018/978-1-4666-9449-1.ch004

Hsiao, K.L., Lu, H.P., Lan, W.C. (2013). The influence of the components of story-telling blogs on readers' travel intentions. Internet Research, 23 (2), 160-182. https://doi. org/10.1108/10662241311313303

Hutton, W. (2005). Describing Greece: Language and literature in the periegesis of Pausanias. Cambridge: CUP.

Jeuring, J.H.G., Peters, K.B.M. (2013). The influence of the weather on tourist experiences: Analyzing travel blog narratives. Journal of Vacation Marketing, 19 (3), 209-219. https://doi. org/10.1177/1356766712457104

Katsoni, V. (2016). An investigation of the tourism distribution channels in the VFR segment. Academica Turistica - Tourism and Innovation Journal, 9 (1), 19-29.

Kelley, J.E. (2015). Excursions into modernism: Women writers, travel, and the body. Londyn: Routledge.

Klimmt, C., Roth, C., Vermeulen, I., Vorderer, P., Roth, F.S. (2012). Forecasting the experience of future entertainment technology: Interactive storytelling and media enjoyment. Games and Culture, 7 (3), 187-208. https://doi.org/10.1177/1555412012451123

Kozinets, R., de Valck, K., Wojnicki, A., Wilner, S. (2010) 'Networked narratives: Understanding word-of-mouth marketing in online communities'. Journal of Marketing, 74, 71-89. https://doi.org/10.1509/jm.74.2.71

Lavie, T., Tractinsky, N. (2004). Assessing dimensions of perceived visual aesthetics of web sites. International Journal of Human Computer Studies, 60 (3), 269-298. https://doi.org/10.1016/j. ijhcs.2003.09.002

Lowe, L. (1991). Critical terrains: French and British orientalisms. Ithaca: Cornell U Press.

MacCormack, S. (2010). Pausanias and his commentator Sir James George Frazer. Classical Receptions Journal, 2 (2), 287-313. https://doi.org/10.1093/crj/clq010

Mattila, A.S., Enz, C.A. (2002). The role of emotions in service encounters. Journal of Service Research, 4 (4), 268-277. https:// doi.org/10.1177/1094670502004004004

McAdams, D. (1996) Personality, modernity and the storied self: A contemporary framework for studying persons. Psychological Inquiry, 7 (4), 295-321. https://doi.org/10.1207/ s15327965pli0704_1

McCabe, S., Foster, C. (2006). The role and function of narrative in tourist interaction. Journal of Tourism and Cultural Change, 4 (3), 194-215. https://doi.org/10.2167/jtcc071.0

McGregor, I., Holmes, J. (1999). How storytelling shapes memory and impressions of relationship events over time. Journal of Personality and Social Psychology, 76 (3), 403-419. https://doi. org/10.1037/0022-3514.76.3.403

McSweeney, R. (2015). Tristes Tropiques by Claude Lévi-Strauss - melancholy anthropology. Pobrane z: https://www.theguardian.com/books/booksblog/2015/aug/17/tristes-tropiques-by-claude-levi-strauss-melancholy-anthropology (25.11.2019).

Moscardo, G. (2010). The shaping of tourist experience: The importance of stories and themes. W: M. Morgan, P. Lugosi, J.R. Brent Richie (red.). The tourism and leisure experience: Consumer and management perspectives (s. 3-26). Bristol: Channel View Publications. https://doi.org/10.21832/9781845411503-006

Neuhofer, B., Buhalis, D., Ladkin, A. (2014). A typology of technology-enhanced tourism experiences. Internatio- nal Journal of Tourism Research, 16, 340-350. https://doi. org/10.1002/jtr.1958

Noy, C. (2004). The trip really changed me: Backpackers' narratives of self-change. Annals of Tourism Research, 31 (1), 78-102. https://doi.org/10.1016/j.annals.2003.08.004

Pace, S. (2008). YouTube: An opportunity for consumer narrative analysis. Qualitative Market Research: An International Journal, 11 (2), 213-226. https://doi.org/10.1108/13522750810864459

Pausanias (1992). Description of Greece. Books I and II. Tłum i wyd. W.H.S. Jones. Cambridge: Harvard U Press.

Pretzler, M. (2011). Pausanias. Travel writing in Ancient Greece. Londyn: Bristol Classical Press.

Pudliner, B.A. (2007). Alternative literature and tourist experience: Travel and tourist weblogs. Journal of Tourism and Cultural Change, 5 (1), 46-59. https://doi.org/10.2167/jtcc051.0

Redfield, R. (1985). Herodotus the tourist. Classical Philology, 80 (2), 97-118. https://doi.org/10.1086/366908

Roberson, S. (2007) Geographies of the self in nineteenth century women's travel writing. W: M. Bruckner, H. Hsu (red.), American literary geographies: Spatial practice and cultural production (s. 281-295). Delaware: University of Delaware Press.

Robin, R. (2008). Digital storytelling: A powerful technology tool for the $21^{\text {st }}$ century. Theory Into Practice, 47 (3), 220-228. https:// doi.org/10.1080/00405840802153916

Sabou, G.C., Nistoreanu, P., Vlad, D. (2014). The ethics of online touristic counselling: A matter of users satisfaction. Contemporary Approaches and Challenges of Tourism Sustainability, $16(8), 98-117$.

Schank, R.C., Abelson, R.P. (1995). Knowledge and memory: The real story. W: S.R. Wyer Jr (red.), Knowledge and memory: The real story (s. 1-85). Hillsdale: NJ. Lawrence Erlbaum Associates.

Schmallegger, D., Carson, D. (2008). Blogs in tourism: Changing approaches to information exchange. Journal of Vacation Marketing, 14 (2), 99-110. https://doi.org/10.1177/1356766707087519

Schulz-Forberg, H. (2005) Unravelling civilization: European travel and travel writing. Bruksela: P.I.E - Peter Lang.

Stanley, H.M. (1890). In darkest Africa. Nowy Jork: Charles Scribner's.

Stewart, R.D. (2013). Most worth remembering, Pausanias, analogy, and classical archaeology. Hesperia, 82, 231-261. https:// doi.org/10.2972/hesperia.82.2.0231

Tussyadiah, P.I., Fesenmaier, R.D. (2016). Marketing destination through first-person stories: A narrative structure analysis. Pobrane z: http://scholarworks.umass.edu/ttra/2007/Presented_Papers/69 (28.11.2019).

Volo, S. (2010). Bloggers' reported tourist experiences: Their utility as a tourism data source and their effect on prospective tourists. Journal of Vacation Marketing, 16 (4), 297-311. https:// doi.org/10.1177/1356766710380884

White, N., White, P. (2004). Travel as transition: Identity and place. Annals of Tourism Research, 31 (1), 200-218. https://doi. org/10.1016/j.annals.2003.10.005

Woodside, A. (2010). Brand-consumer storytelling theory and research: Introduction to a psychology and marketing special issue. Psychology and Marketing, 27 (6), 531-540. https://doi. org/10.1002/mar.20342

Woodside, A., Cruickshank, B., Dehuang, N. (2007). Stories visitors tell about Italian cities as destination icons. Tourism Management, 28 (1), 162-174. https://doi.org/10.1016/j. tourman.2005.10.026

Wu, Q. (2006). Commercialization of digital storytelling: An integrated approach for cultural tourism, the Beijing Olympics and wireless VAS. International Journal of Cultural Studies, 9 (3), 383-394. https://doi.org/10.1177/1367877906066884

Youngs, T. (2013). The Cambridge introduction to travel writing. Cambridge: CUP. https://doi.org/10.1017/CBO9780511843150 